\title{
E-WASTE MANAGEMENT ITS IMPACT ON HEALTH AND ECONOMY-A CASE STUDY UMESH GUPTA ${ }^{\text {a1 }}$ AND KAMAL KISHOR AGRAWAL ${ }^{\text {b }}$
}

\author{
ab Department Commerce, School of Business Studies, MATS University Raipur, C.G., India
}

\begin{abstract}
In India, the quantity of "e-waste" or electronic waste has now become a major problem. Disposal of e-waste is an emerging global environmental and public health issue, as this waste has become the most rapidly growing segment of the formal municipal waste stream in the world. E-waste or Waste Electrical and Electronic Equipment (WEEE) are loosely discarded, surplus, obsolete, broken, electrical or electronic devices. In India most of the waste electronic items are stored at househ olds as people do not know how to discard them. This ever-increasing waste is very complex in nature and is also a rich source of metals such as gold, silver, and copper, which can be recovered and brought back into the production cycle. So e-waste trade and recycling alliances provide employment to many groups of people in India. Around 25,000 workers including children are involved in crude dismantling units in Delhi alone where 10,000-20,000 tonnes of e-waste is handled every year by bare hands. Improper dismantling and processing of e-waste render it perilous to human health and our ecosystem. Electronic equipments contain many hazardous metallic contaminants such as lead, cadmium, and beryllium and brominate flame-retardants, The fraction including iron, copper, aluminum, gold, and other metals in e-waste is over $60 \%$, while plastics account for about $30 \%$ and the hazardous pollutants comprise only about $\mathbf{2 . 7 0 \%}$. Of many toxic heavy metals, lead is the most widely used in electronic devices for various purposes, resulting in a variety of health hazards due to environmental contamination. Lead enters biological systems via food, water, air, and soil. Children are particularly vulnerable to lead poisoning - more so than adults because they absorb more lead from their environment and their nervous system and blood get affected. It is found that the e-waste recycling activities had contributed to the elevated blood lead levels in children living in China, which is one of the popular destinations of e-waste. This was due to that fact that the processes and techniques used during the recycling activities were very primitive.
\end{abstract}

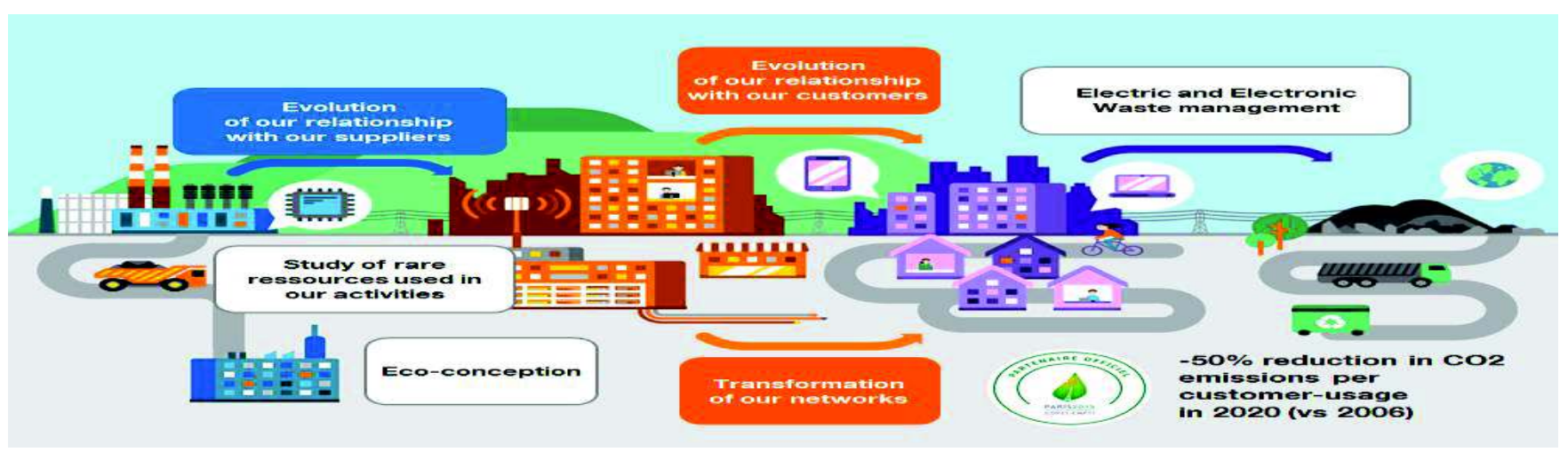

KEYWORDS: Electrical Wastes, Electronic Equipments, Metallic Contaminants

Electronic waste or e-waste describes discarded electrical or electronic devices. Used electronics which are destined for reuse, resale, salvage, recycling, or disposal are also considered e-waste. Informal processing of e-waste in developing countries can lead to adverse human health effects and environmental pollution.

Electronic scrap components, such as CPUs, contain potentially harmful materials such as lead, cadmium, beryllium, or brominated flame retardants. Recycling and disposal of e-waste may involve significant risk to health of workers and communities in developed countries and great care must be taken to avoid unsafe exposure in recycling operations and leaking of materials such as heavy metals from landfills and incinerator ashes.

E-waste or electronic waste is created when an electronic product is discarded after the end of its useful life. The rapid expansion of technology means that a very large amount of e-waste is created every minute.

Electronic waste or e-waste may be defined as discarded computers, office electronic equipment, entertainment device electronics, mobile phones, television sets, and refrigerators. This includes used electronics which 
are destined for reuse, resale, salvage, recycling, or disposal as well as re-usables (working and repairable electronics) and secondary scraps (copper, steel, plastic, etc.). The term "waste" is reserved for residue or material which is dumped by the buyer rather than recycled, including residue from reuse and recycling operations, because loads of surplus
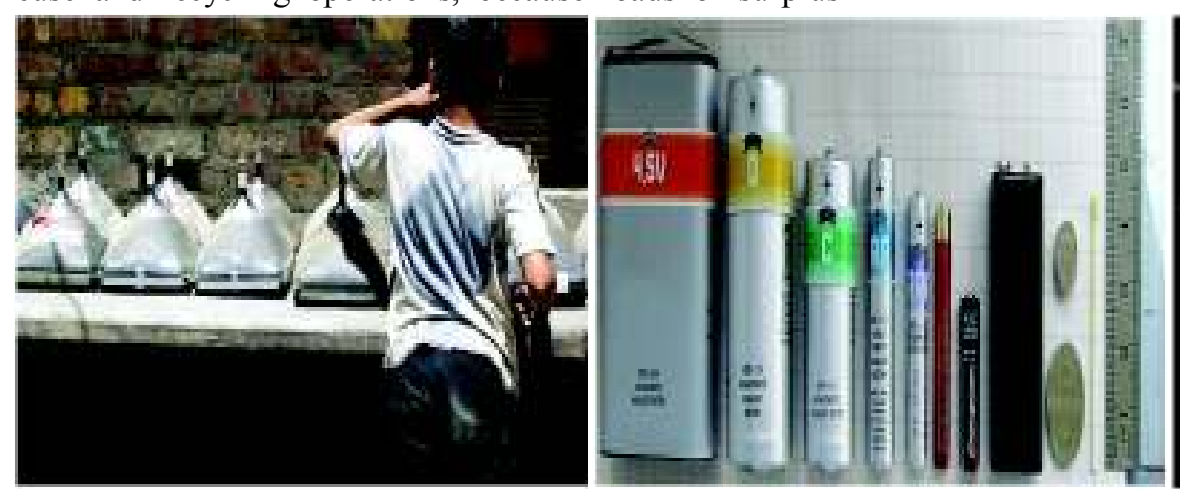

electronics are frequently commingled (good, recyclable, and non-recyclable). Several public policy advocates apply the term "e-waste" and "e-scrap" broadly to all surplus electronics. Cathode ray tubes (CRTs) are considered one of the hardest types to recycle.

\section{E-WASTE PRODUCTS}

\section{Human Health and Safety}

\section{Residents Living Near the Recycling Sites}

Residents living around the e-waste recycling sites, even if they do not involve in e-waste recycling activities, can also face the environmental exposure due to the food, water, and environmental contamination caused by e-waste, because they can easily contact to e-waste contaminated air, water, soil, dust, and food sources. In general, there are three main exposure pathways: inhalation, ingestion, and dermal contact.

Studies show that people living around e-waste recycling sites have a higher daily intake of heavy metals and a more serious body burden. Potential health risks include mental health, impaired cognitive function, and general physical health damage. DNA damage was also found more prevalent in all the e-waste exposed populations (i.e. adults, children, and neonates) than the populations in the control area. DNA breaks can increase the likelihood of wrong replication and thus mutation, as well as lead to cancer if the damage is to a tumor suppressor gene.

\section{Prenatal Exposure and Neonates' Health}

Prenatal exposure to e-waste has found to have adverse effects on human body burden of pollutants of the neonates. In Guiyu, one of the most famous e-waste recycling sites in China, it was found that increased cord blood lead concentration of neonates was associated with parents' participation in e-waste recycling processes, as well as how long the mothers spent living in Guiyu and in ewaste recycling factories or workshops during pregnancy. Besides, a higher placental metallothionein (a small protein marking the exposure of toxic metals) was found among neonates from Guiyu as a result of $\mathrm{Cd}$ exposure, while the higher $\mathrm{Cd}$ level in Guiyu's neonates was related to the involvement in e-waste recycling of their parents. High PFOA exposure of mothers in Guiyu is related to adverse effect on growth of their new-born and the prepotency in this area.

Prenatal exposure to informal e-waste recycling can also lead to several adverse birth outcomes (still birth, low birth weight, low Apgar scores, etc.) and longterm effects such as behavioral and learning problems of the neonates in their future life.

\section{Children}

Children are especially sensitive to e-waste exposure because of several reasons, such as their smaller size, higher metabolism rate, larger surface area in relation to their weight, and multiple exposure pathways (for example, dermal, hand-to-mouth, and take-home exposure).They were measured to have an 8-time potential health risk compared to the adult e-waste recycling 


\section{GUPTA AND AGRAWAL: E-WASTE MANAGEMENT ITS IMPACT ON HEALTH \& ECONOMY-A CASE STUDY}

workers. Studies have found significant higher blood leadlevels (BLL) and blood cadmium levels (BCL) of children living in e-waste recycling area compared to those living in control area. For example, one study found that the average BLL in Guiyu was nearly 1.5 times compared to that in the control site $(15.3 \mathrm{ug} / \mathrm{dL}$ compared to $9.9 \mathrm{ug} / \mathrm{dL})$, while the CDC of the United States has set a reference level for blood lead at $5 \mathrm{ug} / \mathrm{dL}$. The highest concentrations of lead were found in the children of parents whose workshop dealt with circuit boards and the lowest was among those who recycled plastic.

Exposure to e-waste can cause serious health problems to children. Children's exposure to developmental neurotoxins containing in e-waste such as lead, mercury, cadmium, chromium and PBDEs can lead to a higher risk of lower IQ, impaired cognitive function, and other adverse effects. In certain age groups, a decreased lung function of children in e-waste recycling sites has been found. Some studies also found associations between children's e-waste exposure and impaired coagulation, hearing loss, and decreased vaccine antibody tilters in e-waste recycling area.

\section{ECONOMICAL ASPECTS OF E-WASTE}

Societies are producing more and more electronic goods, and therefore more and more electronic waste, or ewaste. The United Nations' Environment Program has released a report that warns of a dangerous rise in the amount of such waste, which is often simply dumped in developing countries, posing health hazards to residents. Every year the world produces 40 million tons of electronic waste: from TVs to refrigerators to cell phones and computers. And this figure will only increase.

For instance, by 2020, China is expected to throw away seven times more cell phones than now, and India 18 times more. These high-technology goods not only are bulky, they often contain toxic materials such as lead and mercury. If the e-waste is not taken care of properly, it can cause pollution and health hazards.

The Basel Action Network is a private group focused on halting the trade in toxic goods, particularly waste goods. Executive director Jim Puckett says the world needs to take urgent measures to end toxic trash. "The industry has built in obsolescence unfortunately, so we're seeing things become waste Quicker than ever before," Puckett said. "Computers now have a life span of about two years now in the North; many mobile phones are turned over within six months when somebody wants to newest model. So we are creating a mountain and we're not going to stop people from consuming. So the first thing we need to do is to get the toxic materials out of the equation".

The issue of e-waste is one of several topics being discussed this week at the United Nation Program for Environment's conference in Nusa Dua, Indonesia.

Achim Steiner, the agency's secretary-general, says much of the e-waste should be recycled. Beyond the environmental reasons, there is also an economic incentive, he says: for example, three percent of the gold and silver mined worldwide is used in personal computers and mobile phones.

"If you start investing and recycling and reusing these materials, you actually begin to look at turning a problem into an opportunity; you start creating jobs, you start reducing the amount of metals that leaves the cycle of our economy, you can reuse them," Steiner said. "So those are all advantages if you begin to manage electronic waste not as we see from industrialized countries to least developed countries without legislation. It is actually being dumped in the backyards of the slums of this world."

The Basel Convention is an international agreement setting global guidelines on handling e-waste. But it is not without weaknesses.

The United States, the single largest producer of ewaste, has never ratified the convention. Also, e-waste has become a highly profitable illegal trade. Some companies get rid of their trash by exporting it to poor countries where, instead of being treated or recycled, it piles up in landfills, and the toxic materials can leach out into water and soil.

"One example that happened in West Africa: they export obsolete cars, and they stuff the cars with obsolete computers hidden in the cars. So we have all those ingenious schemes to do it. And it is actually in that sense very comparable to arms smuggling, and drug smuggling because the incentives are financial and a huge business is to be found in this," said Katharina Kummer, the executive secretary of the Basel Convention. The problem today is compounded by the growing complexity of the trade. Ewaste used to be produced by developed nations and then dumped in poor countries. But today poor countries without recycling capacity export their e-waste to nations like 
China, and emerging economies are also increasingly net producers of e-waste: China for example has become the second larger producer after the United States. Katharina Kummer says there remain limits to how much the traffic can be curbed. "The responsibility of the countries is to adopt legislation and to enforce it," Kummer said. "The problem though is that it requires a huge amount of money, and even the highest developed countries, like the countries of the European Union, do not have the necessary resources to prevent all those illegal exports from happening. So you can imagine what it would look like for a poor country in Africa for example or a poor country from another part of the world".

Electronic waste is more than an economical problem. It also affects the health of millions of people who make a living by stripping out the waste dumped in their countries. Environmental experts say it will take new funds and manpower to solve the problem, by establishing safe recycling facilities and curbing illegal exports.

\section{EXECUTIVE SUMMARY AND CONCLUSION}

E-waste is one of the fastest growing waste streams in the world in terms of volume and its environmental impact on the planet. The existence of precious metals in the e-waste stream provides a major economic benefit for recycling industries but due to the presence of hazardous chemicals, a proper recycling technique is required prior to the disposal of the e-waste.

This paper presents an overview of the statistics on global e-waste generation and the sales of new electrical equipment and electronics in general. The total amount of e-waste produced has reached approximately 41 million tonnes in 2014 and increasing at a rate of 3-5\% every year. A correlation between e-waste generated, gross domestic product and population of the country has also been explored that suggested that the GDP of any country has a direct correlation with the amount of e-waste produced by that country. The population of the country doesn't have a significant impact. The paper also describes the importance and benefits of recycling are emphasized while presenting the techniques currently used by the recycling facilities

\section{Fact-File}

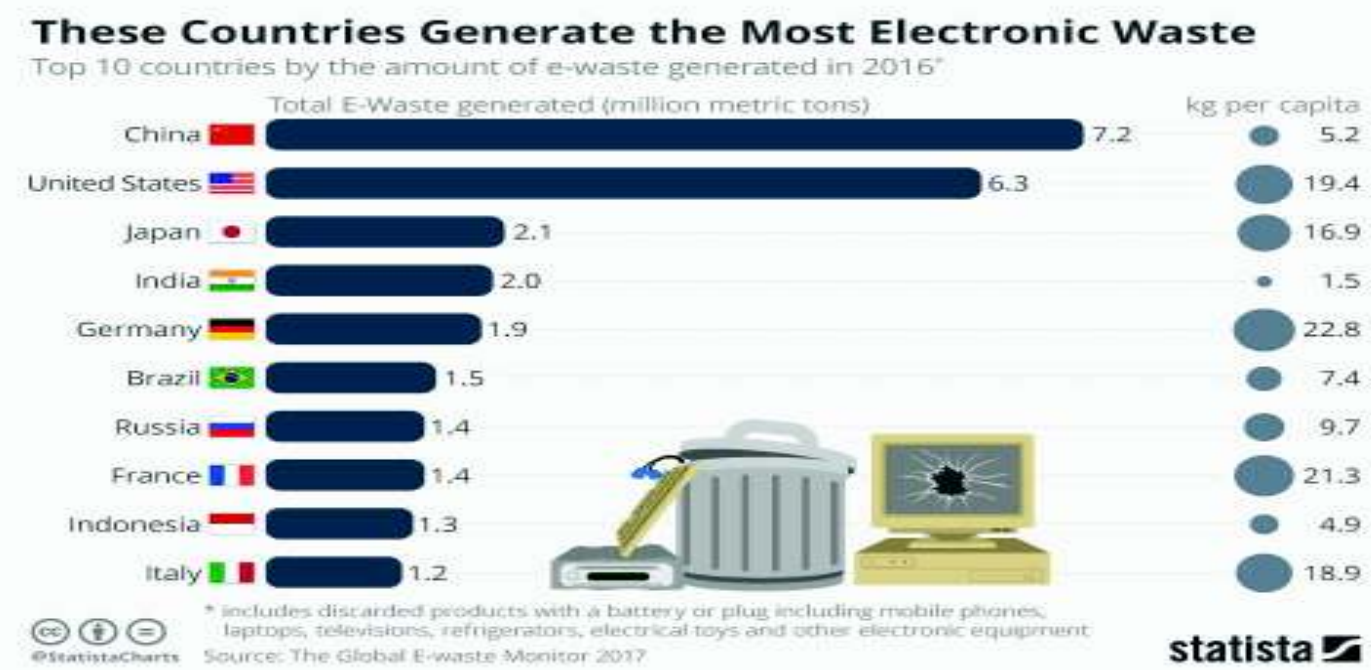

\section{REFERENCES}

https://www.ncbi.nlm.nih.gov/pmc/articles/PMC2963874/

https://en.wikipedia.org/wiki/Electronic_waste

https://www.researchgate.net

https://www.voanews.com https://pbde.bppi.kemenperin.go.id/

https://www.businesstimes.com

https://www.pre-sustainability.com

https://www.createdigital.org.au 